\title{
E-GOVERNANCE MECHANISM IN PAKISTAN: AN ANALYTICAL PERSPECTIVE
}

\author{
Muhammad Ali ${ }^{*}$ \\ Mughees Ahmed ${ }^{* *}$
}

\begin{abstract}
The e-government (short form of electronic government) is a new term which is about the process for decision making and implementing through modern technology. E government refers to improve the efficiency, ensure the accountability, transparency effectiveness of government through the use of Information and Communication Technologies (ICT). It is in this context, the study of e-government has become very important in the literature of social sciences, administrative sciences and public policy studies. In the present scenario, e-government is already in its second decade. More or less all countries around the world are introducing the e-government as a tool for reducing cost, saving time, improving social services and increasing efficiency and effectiveness of public sector. E-government is a comparatively new concept in Pakistan. However, being a developing country, it is facing serious problems regarding adoption of e-government in public services delivery. The underlying aim of this study is to analyze the issues related to electronic governance while focusing on the challenges hindering informed decision making and good governance in Pakistan.
\end{abstract}

Keywords: E-government, good governance, accountability, public service delivery, information and communication technologies (ICT) and smart government

\section{Introduction}

The world witnessed two major changes during early 1990s, namely, focus on good governance for efficient delivery of public services and Information Communication Technologies (ICTs) and internet technologies. Concept of e-governance emerged due to merger of these two changes and it changed the basic philosophy of governance. ${ }^{1}$ With the advancement of technology it became imperative to use this technological advancement for public good as it was successfully being utilized in corporate as well as non-profit sector. Exchange of information is now much more different that it was in recent past that ease of communication can be used in public transactions to save time,

\footnotetext{
* Muhammad Ali, Ph.D. Assistant Professor, Department of Political Science, University of Karachi, Karachi

** Mughees Ahmed, Ph.D., Chairman / Associate Professor, Department of Political Science \&I.R, Government College University, Faisalabad

${ }^{1}$ Andersen , David F. , Salvatore Belardo , and Sharon S. Dawes . 1994. Conceptual Frameworks for Strategic Information Management in the Public Sector. Public Productivity and Management Review 17 (4): pp335 53.

https://www.researchgate.net/publication/256034039_Investigating_the_Potential_of_Mobile_Phones_for_EGovernance_in_Indonesia Access on 26-8-2014
} 
money and other relevant resources. ${ }^{2}$ Over the years, with the development in various technologies, the process of e-governance has been and is continuously influenced positively in developed world. The technological innovations of the past had contributed significantly to improve the efficiency of the processes and systems of governance by altogether eliminating the concepts of time and distance. Unnecessary time consumption in routine transactions and problems caused by distance are successfully tackled by innovative technologies. Historically, the term of e-Governance was absent from dictionaries and encyclopedias until Second World War (1939-1945). Use of ICT in government first expanded during the 1950s and 1960s, the heyday of idea of scientific administration. It got an impetus after the discovery of computer. The explosion of internet use in the mid-1990s gave impetus to an idea of scientific governance and countries such as United States, United Kingdom, Canada, Australia, and New Zealand soon followed with their own version. ${ }^{3}$ The concept of e-governance has gained currency in recent years throughout much of the developed world and increasingly in the developing countries in Asia and Africa. Since the mid-1990s, governments have introduced a slew of initiatives taking advantage of information and communication technologies (ICTs) to support stakeholder relationships and policy goals as well as to improve efficiency, maintain cost effectiveness, and promote transparency and responsiveness in governance.4For a considerable time many terms used to denote the same concept that was associated with e-governance. These interchangeably used terms were/are "Digital government", "Government Online", "e-Government" SMART government, Open -Governance and paperless government.

\section{Significance of the Study}

E-Government is not about "e" but about government. Electronic (or e) government refers to the use of ICT to increase proficiency and efficacy of the government and improve the accountability as well as transparency in decision making. It is also a tool of social service provider to active citizen involvement in governance. Outdated processes and documentation methods hamper efficient and transparent governance today. Use of ICT in governance backed by a networked and digitally enabled government can mitigate this handicap to a large extent. Modern theology based electronic governance will have wide impact not only upon ability to bring economic benefits to the society, but also upon issues related to social, cultural, technological and financial aspects of the community. In this context there has been very little systematic empirical study on impact of e-governance in Pakistan. Given the importance of the subject, it is surprising that this issue has not received much attention. Indigenous and empirical study on the subject is required which could uncover underlying factors impeding improved governance in Pakistan as there is no objective and independent analysis on the subject, and this paper attempts to fill this gap to some extent. Results and findings would be more justified if knowledgeable respondents about E-governance were large in number.

\footnotetext{
${ }^{2}$ Brown, Mary M . 2007. Understanding E-Government Benefits: An Examination of Leading-Edge Local Governments. American Review of Public Administration 37 ( 2 ): p.178 http://arp.sagepub.com/content/37/2/178.shortAccess on 26-09-2015

3 Andrew Chadwick, E-government in Encyclopedia of Governance, (Berkeley: University of California, 2006) p.261

${ }^{4}$ Andersen Op.cit
} 
This study can be stepped forward in future considering the factors individually or combined.

\section{Research Methodology}

This study is strengthened by qualitative and quantitative analysis at a time. Besides, secondary sources such as various books, research articles, journals, and experience of developed countries, books on e-governance web portals, governments official web sites, etc, would also be consulted for this research. The inputs and guidance of the faculty advisor, interview with head of various departments, of the above-mentioned sources shall be analyzed with a view to study the impact of e-governance on public service delivery in Pakistan and hindrances in translating this idea into action. This research paper would discuss four focal points regarding ICT based e-government. Initial section focuses on the brief but comprehensive back ground of research problem. Second part of this paper focused on stages and benefits of e-government through which it provide ease to their citizens. Third part of this paper would evaluate the status of egovernance along with its mechanism and efforts to promote e-governance in Pakistan. Last section of the paper is based on suggestions and concluding remarks.

\section{E-Governments: Conceptual Frame Work}

The e-Governance is complex and multi-faceted concept that is difficult to define in precise terms. There is no single definition of the term "governance" Although the term 'e-governance' has gained currency in recent years; there is no standard definition of this term. ${ }^{5}$ In its simplest sense, e-governance can be defined to be about the use of emerging information and communication technologies to facilitate the processes of government and public administration so as to bring about 'simple, moral, accountable, responsive and transparent' (SMART) governance. ${ }^{6}$ E-government denotes delivery of government services and information to the public using electronic means. ${ }^{7}$ According to Holmes 'electronic governance' means using ICTs at various levels of the government and the public sector and beyond, for the purpose of enhancing governance. ${ }^{8}$ According to Andrew C. "e-government refer to impact of information and communication technology, particular the internet, on the value, processes and outcomes of public bureaucracies." In the views of Kanaujia and Behera, "E-Governance provides opportunities to move forward with high quality, cost effective government services delivery and the creation of better relationship between the people and the government ${ }^{10}$. T.A. Ho described e-government as a "paradigm shift ... transformation in the government's philosophy and organization", as a leap from e-government to e-

\footnotetext{
${ }^{5}$ Löfgren, K.. The Governance of E-Government. A Governance Perspective on the Swedish E Government Strategy, Public Policy and Administration, 2007, 22(3), 335-352

6 Backus, P. E-governance and Developing Countries Introduction and examples, IICD Research Report, No. 3, 2001, pp. 41-51

7 Brown, Op.cit.

8 Holmes D. E-government : E-Business Strategies for government London, (U.K: Nicholas Barkley, 2001) https://www.amazon.com/Egov-Business-Strategies-Douglas-Holmes/dp/1857882792 Access on 26-07-2015 9Chadwik.Op.cit

10Kanaujia and Behera (2006)
} 
governance. ${ }^{11}$ According to Verma ${ }^{12}$ E-government is digital interaction between a government and the citizens (G2C), government and businesses/Commerce (G2B), government and employees (G2E), and also between government and governments /agencies (G2G). The essence of the concept of e-governance is adding to the concept of e-government the involvement of public, private sector and non-governmental organizations into the governance. According to UNESCO (2005) "e-governance is the use of information and communication technologies in public administration in order to improve the information and public service, encouraging the citizens' participation in the decision-making processes and making the government more accountable, transparent and effective" ${ }^{13}$. UNESCO stated the following objectives of e-governance:

- to improve the internal organizational processes of the government;

- to provide information and services better;

- to increase the government's transparency in order to prevent corruption;

- to reinforce political reliability and accountability;

- to promote democratic activity through public participation and consultation. ${ }^{14}$

\section{Phases of e-government}

The theoretical development of e-government in any country or state is along four stages, which indicate the extent of benefits that the stakeholders get through the egovernment plans prevalent in any state.Gartner (2010), has framed a four-phase egovernance model.According to Gartner (2000), the maturity of e-governance goes through four stages (see diagram 1). ${ }^{15}$

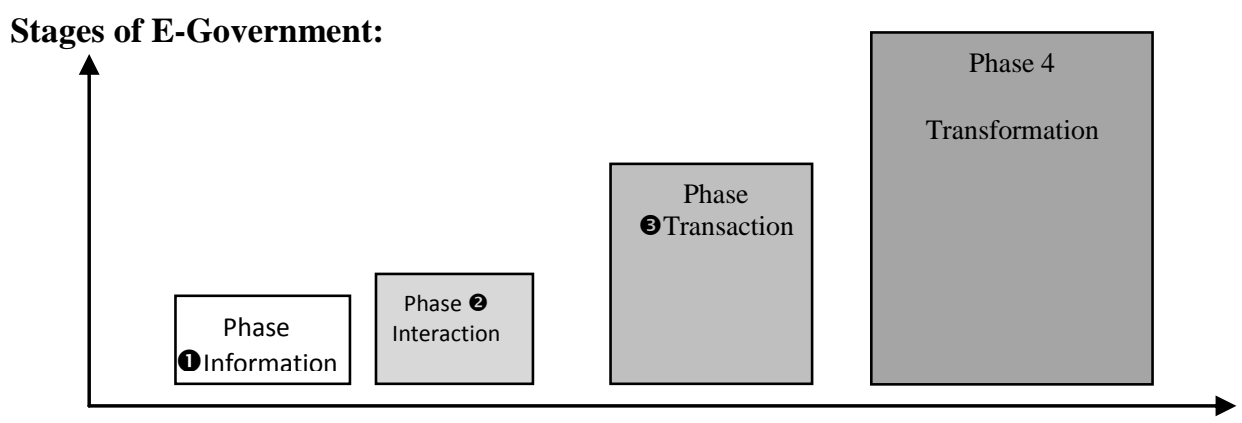

11. Petkaki, D. Accountability in the context of E-Government. In Nixon G. P., Koutrakou V.N, Rawal R. (ed). Understanding E-Government in Europe. (London and New York: Routlege, 2010) p. 96-111. 12Verma Mohan Ram (2005), Democracy and Governance in Changing World, (New Delhi: Vista International Publication House, 2005).

13 Budd, L., Harris, L. (Red.). E-governance: managing or governing? (New York, NY: Routledge, 2009) Access on 16-09-2015

${ }^{14}$ Diana Saparnien (2013) from e-government to e-governance: e-initiatives in Europe, (Lithuania: Siauliai University, 2013) www.nispa.org/files/conferences/2013/papers/201306191000380.Saparniene.pdf?. Cited on 25-07-2016

${ }^{15}$ Gartner. A. Majority of E-Government Initiatives Fail or Fall Short of Expectations, Gartner, Inc.'s Executive Programs, (San Diego: April 2002). 


\section{Information}

Information through web sites is the initial stage of e-government. A few websites are launched that contain limited and static information, which is updated more frequently with increasing usage and customer pressure. The information may be limited to the basic junctions, facts and figures and contact details of government departments and agencies. The information stage does not call for any efforts at 'computerization' of the backend. Interaction: In this stage, the citizens can 'interact' with the government agencies in a 'one-way street' manner. The citizens can download forms, file forms, returns and complaints online, with government agencies. The capacity to search specialized databases and send e-mails to government agencies and links between related web sites are also available. This stage calls for building capacity and systems in the backend government agencies to receive the requests sent by the citizens online and to process the same in a sequential and accountable manner. The interactive websites reduce the tedium of the citizens partially by enabling them to save at least one step in dealing with government agencies. However, this stage has to be handled a bit carefully because, unless the speed and convenience with which citizens can file their requests is matched, to a large extent, by improvements in the backend processes resulting in faster fulfillment, it might result in disenchantment over a period.

\section{Transaction}

This is a much more difficult stage to reach. In the transactional stage, the citizens can go through a full cycle of fulfillment of their requests. It is a two-way street. Complete and secure transactions such as online payments for utility bills, taxes, fees, registrations, renewals, obtaining permits, licenses and certificates are typical examples of interactions, e-procurement, online customs clearances, and single window and Single-Sign-On are more sophisticated examples of this stage. The capacity to permit and sustain online transactions calls for an extensive system study, establishing data centers, disaster recovery and management systems, etc, as the services have to be available on a $24 \times 7$ basis(e.g. 24 hours a day, 7 days a week), and more so, the services have to be citizen-centric and should reflect the transformation that is the hallmark of egovernment. ${ }^{16}$

\section{Integration/Transformation}

This is as yet the Utopian stage of e-government. This stage envisages offering government information and services in an integrated manner-integrated not from the government's point of view but from the citizen or business' viewpoint. A very useful way of envisioning this stage is to package the information and services around the key events in the life cycle of a citizen or business. The integration phase involves removal of not only the jurisdictional limits within an agency but, with more difficulty, of the functional limits and boundaries between departments and agencies. ${ }^{17}$

\footnotetext{
${ }^{16}$ Kanauja.S. Behera, How e-governance striving Indian Panorama, A Panacea for Perfect Government to Citizen Relationship, ( New Delhi India McGraw Hill , 2005) 42-48

${ }^{17}$ Ibid
} 


\section{Background of E-Government in Pakistan}

Pakistan is a developing country and also facing many serious problems in almost every sphere.. E-government is a relatively new concept in Pakistan. As a developing nation the country is facing serious problem regarding good governance and public delivery services. Red tapism is common in public offices and accountability of government official is not inside. For the last two decades various governments have realized the importance of ICTs as emerging field. In Pakistan, internet emerged in 1995 during which internet user population was only few hundred because of limited internet services in limited cities. Since the early 2000s, during the era of General Pervaiz Musharraf (1999-2008) ICT was one of the fastest growing industries in the country. . In 2002 the Ministry of Information and Technology has been setup) where this ministry has flourished and gradually its improving performance. Past ten years have witnessed landmark developments in the field of telecommunications. According to International Telecommunications Union (ITU), In 2015, $11 \%$ of the population is using internet in Pakistan. Moreover, 3G and 4G service is available in the country since 2014. The government had earned $\$ 1.1$ billion at time of auction. Major reason of this increase is the government's policy to take concrete measures to connect the remotest areas of the country with the internet access. ${ }^{18}$ Government of Pakistan seriously recognized the importance of information technology and launched a number of projects to equip the people of both rural and urban areas with modern Information Technology applications. Since its establishment in 2002, the Ministry of Information and Technology (MoIT) and EDG ICT is playing a pivotal role in the society. Important institutions like National Database and Registration Authority (NADRA) and CPLC (Citizen Police Liaison Committee) have been established. NADRA, is the leading institution that claims to be the biggest IT based public organization of the country and offers its clients a portfolio of customizable solutions for identification, e-governance and secure documents. ${ }^{19}$ CPLC (Citizen Police Liaison Committee) is another highlighted institution in Pakistan and is being flourishing through which citizen can check the vehicle registration information online service is available. The Government of Pakistan started online vehicle verification from three different provinces in Pakistan. ${ }^{20}$

\section{Why E-Government is Important in Pakistan?}

E-government is about the process for decision making and implementing through modern technology. E-government is also called as SMART government. The acronym of SMART is referred to making government, Simple, Moral, Accountable, Responsive and Transparent (SMART). It is in this context, the study of e-government in Pakistan has become very important in the literature development studies. It is important for several benefits.

18Internet Users In Pakistan 2015http://odosta.com/internet-users-in-pakistan-2015/Accessed on 04-01-2016 19 NADRA http://www.nadra.gov.pk/index.php/about-us/profileAccessed on 04-01-2015

20 Electronic Government Directorate (EGD) http://www.e-government.gov.pk/Accessed on 04-01-2015 


\section{E-government as a mechanism for Promotion of good governance}

It is widely believed that e-governance can be an effective tool to establish good governance. 'Governance' is the process of decision making and implementing and is used in different aspects. Some times in the form of local governance, corporate governance, national governance and international governance. ${ }^{\mathbf{2 1}}$ When a group of people comes together to an end the governance is needed, in that situation the central component of governance become decision-making. Good governance is citizen caring and corruption free, and citizens are active in decision-making. Good governance results in organizational effectiveness both in public and non-profit sectors. So precisely, it can be said that the objectives of e-governance and good governance are quite similar to each other.

\section{E-Government as a Tool of Eliminating Corruption}

The developing countries particular, Pakistan is in a great challenge to fight corruption that has got rise because of improper administrative transparency, lack of accountability and absence for monitoring process. The fundamental rights of the citizens are also suppressed due to manual paper-based administrative system. This can be successfully reduced with the implementation of E-governance. ${ }^{22}$ It is not expected that egovernance will eliminate all the corruption from the country but it is expected to improve the overall scenario of governance and the impact will flow to improve the corruption situations. Though not stated often explicitly, control of corruption is on the agenda of any major e-government initiative. However, control of corruption is not taken up and canvassed as one of the benefits of e-government for two reasons-first no government would like to go on record that corruption exists in its operations; secondly, such a stance would pit the government against its employees and thereby the egovernment initiative would be a non-starter.

\section{E-Government: As a Tool for Electronic Service Delivery (online not in line)}

Electronic Service Delivery (ESD) is obviously beneficial to the citizens and other customers of the government in a variety of ways. E-government projects in the social sectors, especially in the areas of welfare, health and education in the context of developing countries particularly in Pakistan, bring in the benefits arising out of better targeting of benefit schemes. Electronic databases of citizens, employees and establishments, use of electronic identity cards, coupled with powerful search tools, name-based systems and the like, result in identification of the most deserving beneficiaries among the target group, reduces the scope for duplication of benefits to the same individual or for drawing of benefits in the name of fictitious persons and institutions. Better image would be propagating with speed, efficiency, transparency and convenience arising of ESD enhances the image of government. This is in fact one of

\footnotetext{
${ }^{21}$ RamakantRao, (2008) Good Governance Modern Global And Regional Perspective, MG. Kaniska Publisher Distributors, New Dehli, , pp.10-11

${ }^{22}$ Rajon, S. A. A and Zaman, S. A.(2008): "Implementation of E- Governance :Only Way to Build a Corruption-Free Bangladesh." Proceedings of 11 (ICCIT), pp. 430-435

KaziTareq and Nurunnabi (2009) E-Governance As An Anti-Corruption Tool for Government in Bangladesh AIUB Journal of Business and Economics Volume 8, Number 2August 2009 pp. 143-164
} 
the strongest factors driving governments all over the world towards e-government. Of late, e-government has been figuring prominently in the election manifestos in several democracies.

\section{E-Governance as tool for Citizen Empowerment}

The primary purpose of Government to Citizen (G2C ) is to make government, citizenfriendly. It is aimed at empowering the citizen. The appeal of e-government arises from its promise of providing efficient and convenient services to citizens. The value proposition of e-government can be better understood if we compute the 'real' cost to the citizen of securing a service from the government agencies, more so in relation to the developing countries. The dc jure or statutory fee payable for securing government service is usually very low. However, the de facto or 'real' cost could be 10 or 20 times the statutory fee. The real cost includes expenditure that the citizen has to incur on ascertaining the forms and procedure appropriate to the service needed, travelling to the designated government agency or to an intermediary/agent multiple times, the 'speed money' required to be paid for certain transactions-besides the loss of wages for the period of time spent on getting the service. The direct and indirect costs of providing citizen services in the conventional way are far higher than in the case of electronic delivery. ${ }^{23}$ (2005). Besides cost reduction, the other benefits to citizen can be in the form of

- increased transparency leading to reduced corruption,

- better planning of personal and professional work in dealing with the government,

- better quality of life as a result of the use of ICT in areas such as health, education, employment, welfare and finance,

- easy access to information on government agencies and programmes,

- multiple delivery channels to choose from, thus adding to convenience. ${ }^{24}$

\section{E-Government: Benefits to Business or E-Commerce}

The G2B interaction typically involve the use of technology to reduce operational cost, save time, cut red tape of the government of buying and selling good services from firm. The businesses also derive most of the benefits mentioned above, namely, cost reduction, transparency and convenience. Besides these, there are a few distinct additional benefits that they get from a well-designed e-government initiative. These benefits are as follows:

- Increased velocity of business, interaction with bureaucratic governments is one of the impediments to the growth of industry and business. With the digitalization of the G2B (Government to Business) interface, the velocity of business increases. Ease of filing returns under various statutes and enhanced

\footnotetext{
${ }^{23}$ (Kanauja.S. Behera 2005:)
}

${ }^{24}$ Ibid. 
speed in securing the various permits and licenses through electronic single windows are examples worth noting.

- Ease of doing business with government, e-procurement, implemented in a few countries like Chile ,USA, Japan, Singapore and European Union, not only create transparency but IT also enhance of doing business with government. ${ }^{25}$

\section{E-Government: Benefits to IT Industry}

The ICT industry is a special stakeholder in the e-government movement because governments all over the world are the largest single spenders on ICT, even though egovernment is still at a nascent stage. If e-government were to become a priority and a part of the vision of all democratic governments, the biggest beneficiary would be the ICT industry, spanning across its various segments such as software, hardware, networking, storage, security, consultancy, IT education, training, and facilities management. However, there is yet another potential benefit that the ICT industry can exploit, by virtue of its unique position. That is by partnering with governments in implementing e-government through a cost-effective and sustainable business model. Public-Private Partnership is getting recognized increasingly as an efficient means of implementing e-government. Suffice it to state here that the ICT industry is strategically positioned to be not only the biggest commercial beneficiary of e-government but also of being a proud partner in its success.

\section{Disadvantages of E-government}

Despite its significance, the process of E-governance is not free from critics. The chief drawbacks of e-governance are the absence of equality in public access to the electronic means, for instance, internet, reliability of information on the website. Another setback is inaccessibility potential of many users especially those who live in remote areas, have low literacy levels, exist on poverty line incomes." Establishment of e-government agencies cost a huge sum of money which is a setback for a developing country. The system of person to person interaction has lost which is valued by a lot of people in today's society. The e-government may result in complete in partial loss of person to person contact, hence disruption of social values .It affects personal privacy because it is limited to a minimum level and it is inevitable in e-government. There is no personal privacy exist when the government interfere in private information.

\section{Barriers Challenges for E-Governance in Pakistan}

Despite lot of encouragement in implementation of e-governance; various challenges are there to meet. E-governance becomes failure in many countries around the world especially in developing countries. E-governance projects may face challenges due to multiple reasons. Following are few challenges and barriers that can delay process of egovernment implementation in Pakistan: The reasons are as follows:

${ }^{25}$ Ibid . 
- Lack of technical human resource, technical training and ICT infrastructure are major bottlenecks for the introductions of egovernance.

- Lack of collaboration and interaction between different departments and agencies of government

- Accessibility of Internet very limited area covered by internet service providers to general public as well as government

- Lack of will and conservative mind set of bureaucracy in order to keep red tapism alive

- Acceptability of electronic documents officially and legally.

- Inadequate understanding about utilizing and importance of e-governance among masses.

\section{Policy Recommendations}

- After analyzing the present scenario of e-governance in Pakistan, the following suggestions are also found as strength in external environment, which can be treated as basement for e-governance implementation along with technological preparation of government. Following serious attention should be given by both of government and citizens

- Legal framework is required for the e-government in Pakistan.

- Geographical proximity for ICT infrastructure.

- International support is needed for both of technical and financial.

- Education about e-governance including the utilization and importance can be generated through media publicity, seminars, workshops and also pilot testing as for example.

- The governments need to adopt information society tools in order to remain responsive to citizen's needs.

- Help in strengthening civic engagement and public trust.

- The internet and other advanced communication technologies can bring information quickly and more directly to citizens.

- Involvement of civil society could be beneficial for the promotion of egovernance in Pakistan.

- Lateral entry of efficient people in government services who believe in change and process of governance. 


\section{Conclusions}

E government refers to improve the efficiency, ensure the accountability, transparency of government through the use of ICT. In the age of globalization, More or less all countries around the world are introducing the e-government as a tool for reducing cost, saving time, improving social services and increasing efficiency and effectiveness of public sector. E-government is a comparatively new concept in Pakistan. Being a developing country, Pakistan is going through its primary phase .Many more efforts have to be made to become an effective e-government structure in Pakistan. A good start has been made where the citizens of Pakistan can also get benefits from e-government. Ease in the access of technologies and online services are the main benefits for egovernment in developing countries. These days Pakistan shows its rapid growth towards achieving the desired goal in electronic government to deliver its e-services with efficiently to the citizens and businesses. E-government has been identified as one of the priorities for Pakistani government and all its agencies. However, adoption of egovernment is facing many challenges and barriers such as lack of infrastructure, conservative mind set of bureaucracy, language barrier and low literacy rate - which must be considered and treated carefully by government contemplating its adoption. Pakistan also needs to revamp its national level documentation and information structures and start transition towards e-governance. This can be achieved by a process of sector wise development and creation of system based integrated networking. Thus by a concerted intra departmental integration process a practical step towards egovernance can be initiated. It can therefore be safely concluded that e-governance betters the service delivery and informed decision-making through public participation which ultimately leads to economic benefits for the society.

\section{Bibliography}

Andersen, David F., Salvatore Belardo, and Sharon S. Dawes. 1994. Conceptual Frameworks for Strategic Information Management in the Public Sector. Public Productivity and Management Review 17 (4): pp335 - 53.

https://www.researchgate.net/publication/256034039_Investigating_the_Potential_of_M obile_Phones_for_E-Governance_in_Indonesia Access on 26-8-2014

Andrew Chandwik(2006) E-government in Encyclopedia of Governance, University of California, Berkely p.261

Backus, P.(2001): E-governance and Developing Countries Introduction and examples, IICD Research Report, No. 3, pp. 41-51

Brown, Mary M . 2007. Understanding E-Government Benefits: An Examination of Leading-Edge Local Governments .American Review of Public Administration 37 (2): pp.178 http://arp.sagepub.com/content/37/2/178.shortAccess on 26-09-2015

Budd, L., Harris, L. (Red.). (2009). E-governance: managing or governing? New York, NY: RoutledgeAccess on 16-09-2015

Diana Saparnien (2013) from e-government to e-governance: e-initiatives in Europe, Siauliai University, Lithuania 
www.nispa.org/files/conferences/2013/papers/201306191000380.Saparniene.pdf?. Cited on 25-07-2016

Electronic Government Directorate (EGD) http://www.e-government.gov.pk/Accessed on 04-01-2015

Gartner. A Majority of E-Government Initiatives Fail or Fall Short of Expectations, Gartner, Inc.'s Executive Programs, San Diego, April 2002.

Holmes d. (2001) E-government: E-Business Strategies for government London, U.K, Nicholas Barkley https://www.amazon.com/Egov-Business-Strategies-DouglasHolmes/dp/1857882792 Access on 26-07-2015

Internet Users In Pakistan 2015http://odosta.com/internet-users-in-pakistan2015/Accessed on 04-01-2016

Kanauja.S Behera (2005) How e-governance striving Indian Panorama, A Panacea for Perfect Government to Citizen Relationship, New Delhi India McGraw Hill PP-42-48

KaziTareq and Nurunnabi (2009) E-Governance As An Anti-Corruption Tool for Government in Bangladesh AIUB Journal of Business and Economics Volume 8, Number 2August 2009 pp. 143-164

Löfgren, K. (2007). The Governance of E-Government. A Governance Perspective on the Swedish E Government Strategy, Public Policy and Administration, 22(3), 335-352

NADRA http://www.nadra.gov.pk/index.php/about-us/profileAccessed on 04-01-2015

Petkaki, D. (2010). Accountability in the context of E-Government. In Nixon G. P., Koutrakou V.N, Rawal R. (ed .). Understanding E-Government in Europe. (London and New York, Routlege, 2010) 96-111.

Rajon, S. A. A and Zaman, S. A.(2008): "Implementation of E- Governance :Only Way to Build a Corruption-Free Bangladesh.” Proceedings of 11 (ICCIT), pp. 430-435

RamakantRao, (2008) Good Governance Modern Global And Regional Perspective, MG. Kaniska Publisher Distributors, New Dehli, , pp.10-11

Verma Mohan Ram, Democracy and Governance in Changing World, (New Dehli, Vista International Publication House, 2005) 